\title{
The Presence of Country State in Improving Educational Quality in Indonesia towards Competition in ASEAN Community 2015
}

\author{
Budiharjo \\ University of Prof. Dr. Moestopo (Beragama) \\ Jl. Hang Lekir I No. 8, Senayan, Jakarta 10270, Indonesia \\ budiharjo@dsn.moestopo.ac.id
}

\begin{abstract}
The establishment of the ASEAN Community will make every ASEAN country involved in the global market. Education is a vital and strategic sector in improving the development of human resources to encounter the global market. Free labor market will occur in the ASEAN Community in 2015. Indonesia must design an education reform to produce competitive human resources at the regional level. Therefore, this paper presents analysis of the presence of country state in improving educational quality in Indonesia towards competition in ASEAN community 2015. The role of a strong country state is needed to make Indonesia competitive in the ASEAN community.
\end{abstract}

Keywords: ASEAN Community; Education; Challenge; Opportunity.

\section{Introduction}

The leaders of ASEAN countries agreed to form an ASEAN Community in the 9th ASEAN Summit in 2003. This commitment to form ASEAN Community is reaffirmed in 12th ASEAN Summit in 2007 to have it realized in 2015. There are three pillars of ASEAN Community, namely ASEAN Political-Security Community (APSC), ASEAN Economic Community (AEC), and ASEAN Socio-Cultural Community (ASCC). Shi proposed the idea of future energy mix in ASEAN using A SWOT analysis [1]. Yajid and Rahmat discussed the challenge of ratification and application of specific regional based declaration for railway industry in ASEAN mainland: the national culture perspective [2]. The ASEAN Community can be achieved if ASEAN member countries focus not only on their own domestic interests, but also on regional development. Opasanon and Kitthamkesorn presented the simulation based approach about border crossing design in light of the ASEAN Economic Community [3]. By the presence of ASEAN Community in 2015, ASEAN member countries will start accentuating human resources development as the key in national development to get into global knowledge- and environmentalbased economy. Srisuruk and Silanoi presented the effect of training package development in preparing the readiness for secondary school students in the northeastern of Thailand toward ASEAN Community [4]. Sukmadilaga et al. presented good governance implementation in public sector: exploratory analysis of government financial statements disclosures across ASEAN countries [5].

The establishment of ASEAN Community means that every ASEAN country will enter an environment known as global market. Jitpaisanwattana et al. presented the analysis and synthesis on education management for readiness preparation of Thai workforce in accounting for the ASEAN Community [6]. In the global market, knowledge and information technology are vital as the primary drive of development. Zhang et al. presented the influence of curriculum quality and educational service quality on student experiences: A case study in sport management programs [7]. Education, as one of the basic human rights, is considered strategic for the improvement of human resources development in facing the global market. Niculescu present the classroom leadership to 
improve the quality of the educational process [8]. Chalaris et al. discussed how to improve the quality of educational processes providing new knowledge using data mining techniques [9]. The right for education obliges countries to ensure that all children and citizens have equal opportunity to get education.

In this matter, ASEAN countries have the obligation to improve the quality and equity of education. This obligation becomes a general policy to be conducted by countries in Southeast Asia regardless of the diversity in their development level. Therefore, this paper presents analysis of the presence of country state in improving educational quality in Indonesia towards competition in ASEAN community 2015. The role of a strong country state is needed to make Indonesia competitive in the ASEAN community.

The rest of the paper is organized as follow. Section 2 presents proposed methodology. Section 3 presents result and following by discussion. Finally, the conclusion of this work is described in section 4 .

\section{Proposed Method}

This research employs qualitative approach. The aim of this qualitative approach is to draw empiric reality behind a phenomenon comprehensively, specifically and completely. The phenomenon analyzed is the processes of educational activities in ASEAN area on the basis of reality in the field as materials for further study to discover and recognize the deficiency and debility of education so as to determine the ways to perfect it.

\section{Result and Discussion}

\subsection{The Importance of Education Sector in ASEAN}

The importance of collaboration in education in ASEAN is mandated in ASEAN Declaration, ASEAN Vision 2020, and ASEAN Charter. These three grounds call ASEAN countries to live in prosperity, peace, and stability, and share a bond in a dynamic partnership and development. Moreover, ASEAN Charter also stipulates that one of the goals of ASEAN is "to develop human resources through close cooperation in education and learning, and in science and technology, for the empowerment of ASEAN people and reinforcement of ASEAN Community" [10].

Education sector is vital for ASEAN commitment to form ASEAN Community in 2015 proposed by the leaders of ASEAN countries [11]. Cha-Am Hua Hin Declaration on Strengthening Cooperation on Education to Achieve an ASEAN Caring and Sharing Community adopted on 24 October 2009 states that education sector is expected to contribute to the formation of ASEAN Community. By improving development in education sector, every country has conducted social responsibility where the country will improve the welfare of its citizens. Education is also expected to improve competitiveness of each ASEAN country member [12].

In the matter of Higher Education development in ASEAN, the extensive strategic goal to be achieved is to guarantee educational integrity in ASEAN development. Development in education sector aims at advancing and prioritizing education that focuses on: 1) creating knowledge-based society; 2) achieving universal access for basic knowledge; 3) motivating concern and development of infants; and 4) improving ASEAN youth awareness through education and activities to construct ASEAN identity on the basis of friendship and collaboration.

Some challenges for higher education in Southeast Asia are: 1) the lack of quality teachers, 2) limited experience and quality of education quality guarantee processes, 3) the lack of equal access of knowledge for students, 4) the lack of educational infrastructure, and 5) limited English using facility and research skills [13]. 
In ASEAN Community, there will be free labor market in 2015 and higher education of the region must be reinforced with strategies to face this challenge. The strategies conducted are [13]:

- Regional Accreditation (APACC) aiming at accredited and certification of technical and vocational education and training (TVET) institution through a general quality framework facilitating the mobility of labor in the region.

- Integrated Education Framework, conducted by setting a standard for ASEAN higher education curriculum. As the consequence, every ASEAN country must revise curriculum in all programs to meet the demand of labor market.

- Education Quality Improvement. At present, countries in Asia face the problems of insufficient skilled labor, both men and women.

- Scholarship for students (Faculty Exchange). It aims at giving opportunities to ASEAN youths in developing their potentials and providing them with skills that will allow them to confidently step to larger communities.

- Regional Skills Competition. This competition will stimulate participation of higher education institutions and TVET institutions to support development of labor and achieve regional competency standard.

- Improving English usage. The labors must realize the importance of possessing communication skill in English.

- E-learning/ online learning/ distance learning/ open learning. Some countries in Southeast Asia region must improve the number of open universities. Open learning system is not only for university and TVET level, but also for teacher training programs.

- Universal Education (access, equity, and quality). Not all ASEAN countries are able to provide free education like Brunei Darussalam, which provides free education for all citizens from the age of five to university level.

There are some important points in education sector which will be actualized in ASEAN Community, namely [14] Developing national skill framework into ASEAN skill framework; 2) Motivating higher mobility of the students; 3) Greater mobility support for skilled labor through regional cooperation mechanism and with the effort to maintain and improve standard of education and professionalism; 4) Developing jobs based on ASEAN competency standard; and 5) Motivating development of general competency standard as the ground for benchmarking in order to stimulate ASEAN inter-countries competency acknowledgement.

\subsection{Education Sector in Some ASEAN Countries towards ASEAN Community 2015}

In the preparation towards ASEAN Community 2015, some ASEAN countries design several educational policies [15]. For instance, in Thailand [16], the level of education of Thailand labors is in constant improvement. Thai Government actively works on improving education in Thailand since the announcement of National Education Development Scheme in 1932. This scheme aims at motivating the creation of knowledge-based economy focusing on innovation in technology sector. Since 2002, Thailand has succeeded in creating compulsory education which obliges Thai citizen to achieve at least 9 years of compulsory education under government support. Moreover, higher education can be accessed easily due to the presence of student loan in 1996. In recent time, the government of Thailand formulates The Eleventh Social and Economic Development National Plan (2012-2016) by prioritizing the development of knowledgeable and skillful human resources. In the last ten years, the Department of Science and Technology provide more than 3,000 scholarships in science and technology, from undergraduate to doctorate level. Several programs have also been conducted to develop quality technicians through science- and technology-based schools, integrated 
learning work program, education system cooperation in universities, and education program through Science School. The efforts conducted by the country have succeeded in improving the number of qualified labors for national labor market. The average growth rate of Master degree labor is increasing. In 2012, the percentage of labors holding high degree in Thai workforce increases to almost 18 percent.

In addition, in Thailand [17], the Department of Culture is also considering to establish ASEAN division to deal with cultural matters between Thailand and other members of ASEAN. The Education Department also improves vocational education in preparation for realization of ASEAN Community in 2015. The Department of Education has the policy of giving big boost to vocational education in order to improve Thailand competitiveness in the next four years. Skill development will help developing human resources, allowing Thailand workers to keep being competitive in global market.

Meanwhile, the Philippine stipulates The Philippine Education for All (PUS) 2015 policy [18]. This is the holistic reform vision and program aims at improving the quality of basic education for every Philippine citizen in 2015. This program is surfaced in April 2000 in Dakar, Senegal, and adopted by various countries participating, including the Philippine. The aim of this program is providing basic competency for all people in order to achieve functional literacy for all. This program ensures that every Philippine citizen will have equal basic competency by providing basic education needs.

Meanwhile, education in Cambodia is still left behind compared to the majority of Southeast Asia countries. This situation is certainly the main obstacle in utilizing AEC opportunities. This country has the lowest literacy rate in the world (73.9 percent in 2012), and also low Human Development Index in ASEAN. Moreover, labor market in this country is signified with discrepancy and skill gap caused by lack of motivation, and insufficient education and training. In labor mobility, Cambodia is exporter of labors, but most of them are low skilled workers seeking for jobs without legal documentary and not included in free flow of labors in AEC. Cambodian migrant labor is susceptible to exploitation and violation of human rights. Cambodia is benefited by AEC since with the presence of AEC, Cambodia can import skilled workers from ASEAN countries [19].

The presence of AEC will motivate ASEAN countries to produce labors with high skill and more productivity that can compete in regional market. With this effort, the country will not depend on low skilled labors to boost export and economic development. Aware of this opportunity, it takes enforcement of national education and training system to make sure that the labors produced have the qualification and competency needed to compete in ASEAN [15].

Putting aside the importance of development in human resources, the state has the obligation to provide basic education, and literacy and calculation skills. In this matter, ASEAN member countries are in a quite strong position. The literacy level among work age population is relatively high-except in Cambodia and Laos, where the literacy level is less than 75 percent. ASEAN Member Countries have achieved universal education in the matter of basic education. However, in the entire region, almost three million kids at elementary school age do not go to school. This is because they are never registered to school at all. They take the risk of becoming child labor and are impossible to acquire sufficient literacy and skill required by job opening. More than 80 percent of these children are in Indonesia and the Philippine. The Philippine also has the highest proportion of drop outs. The problem of drop outs also transpires in Brunei Darussalam, Laos and Thailand.

The highest deficit of middle school education is in Cambodia, Laos and Myanmar, where pure participation number is less than 50 percent. In Indonesia, Malaysia, the Philippine, and Thailand, the middle school education participant is higher, but still not universal. Vocational education participation is also weak in most of ASEAN member countries, in particular among young women. In this matter, Viet Nam has started improving education for minority ethnics and girls in underdeveloped areas by building 
schools and teacher housings, developing classrooms, and free meal at school program. Similarly, Indonesia stimulates participation of girls in impoverished rural areas through grants managed by school committee in form of scholarships, supplemental meal, transportation and separated sanitation facility [15, 20-22]. ASEAN Countries with middle to high economic growth rate also face challenges related to low availability of university graduates with diploma in engineering, manufacture and construction-9.3 percent in Brunei Darussalam, 15.6 percent in Thailand, and 27.3 percent in Malaysiaand significantly lower for women. Thailand, for instance, has a surplus of social science graduates and too little specialists in science, technology, and healthcare. Thus, around 80 percent of corporations in Thailand have difficulty in filling job openings since most of the graduates do not have the related technical skills.

Although there are various challenges at macro and micro levels in all ASEAN countries, the ASEAN Secretariat's five-year Work Plan on Education tries to surpass these challenges through access to quality education, cross borders mobility, and education internationalization, as well as supports to other sectors that need education program input. Macro challenge can be perceived from the presence of "corruption and politics" crime. A key question is how long does it take for the government to complete and surpass socio-political, socio-cultural and socio-economic challenges. This certainly requires optimum role of higher education institutions. The AEC 2015 will provide opportunities for local higher education institutions to improve the quality of their educational performance to compete in national, regional and international levels. Every ASEAN country can execute education reform at macro level through [23]:

- Increasing the quality, efficiency and effectiveness of higher education in regional education arena to be more competitive and open through the practice of accreditation and law enforcement.

- Providing aid to students targeted at all levels of education and procurement of public fund and adequate infrastructure needed in education reform.

- Reconstructing education system through policy adjustment and performing education reform in both formal and informal education access. In addition, also improving services for all levels of society to improve better education access for all students.

- Minimizing corruption and politicization of education reform. This must be performed by ASEAN member countries for the advancement of society and the form of government social responsibility to people.

At micro level [23], challenges faced by each higher education institution is the need to implement various activities such as student and teacher exchanges, joint academic program, establishment of international campus in ASEAN/Asia, and production of English-based programs. In this matter, higher education is demanded to have international criteria without ignoring local values, and providing services as required at local level.

Various efforts can be conducted to help reform the education system and improve learning process, such as the one conducted in Thailand that help improve the instruction quality of middle school. This initiative is performed through the construction of teacher licensing system, extension of pre-service and in-service training, procurement of awards for extraordinary teacher performance, and escalation of teacher's compensation. Similar thing occurs in Malaysia. In order to improve the quality of education, Malaysia develops quality standard system, practices learning reorientation of information and science, and provides mathematics and science teachings in English. This is of course supported by improving teacher's qualification. The curriculum reform also becomes vital in enhancing competitiveness of education sector. Curriculum reform also aims at stimulating flexibility and relevance of education to prepare for more-ready workforce in ASEAN. This goal certainly requires great education financing sources. However, in ASEAN, there are also countries still lacking in providing financial support for education sector. This is the case in Myanmar where public expenses for education is 
less than one percent of GDP. This financing is far less than three percent in most of ASEAN member countries [15].

\subsection{Indonesia Education Sector in ASEAN Community 2015}

The presence of AEC will not only influence free trading sector for various goods, but also labor sector. With AEC, ASEAN countries will compete freely to fill labor sector in ASEAN. For countries whose labors have good education and competency qualification, AEC will be the opportunity to extend their labors to other ASEAN countries. The Central Bureau of Statistics (BPS) in August 2013 states that the number of Indonesian workers with elementary school qualification and below is amounted to 52 millions (46.93 percent) or almost half of all workers in Indonesia. Meanwhile, workers with Junior High School qualification are 20.5 millions (18.5 percent), and workers with Senior High School qualification are 17,840,000 (16.1 percent). On the other hand, the number of worker with university graduate qualification is at the lowest of 6.83 persen. As a comparison, according to the Department of Statistics Malaysia (DOSM) in 2012, the number of Malaysian labor is 13,120,000 with total of 7,320,000 (55.79 percent) are high school graduates and 3.19 millions (24.37 percent) are university graduates and diploma holders. Other ASEAN countries, such as Singapore, according to the data from World Bank in 2012 has total labor number of 3,220,000, with 49.9 percent of them have Senior High School qualification and 29.4 percent university graduates and diploma holders qualification. These data show that almost half of Indonesian labors (46.93 percent) work at low skilled labor sector. This is different to the case of Singapore and Malaysia where 80 percent of their labors are high school and university graduates. It shows that Indonesia is not ready for labor market in ASEAN. The root of the problem of low level of Indonesian labor qualification is primarily due to the lack of access to higher education due to the high cost of education in Indonesia [24].

Keeping in mind the above mentioned problem, the fundamental thing that Indonesian government needs to prioritize in facing AEC in 2015 is improving education orientation and development of human resources. Some steps regarded as necessary to do are as follow [24]: First, the government must prioritize, in the next five years, improvement of labor education qualification which for the most part are elementary school graduates, to be enhanced to at least high school graduates. This is vital to do so that workers can defend themselves and compete after AEC is in progress. Second, the government is expected to eradicate systemic corruption in education sector. This is necessary since education financing is the primary source for the government in executing educational programs. Third, Indonesia must gradually conduct reform in education policy that can support the implementation of free education to university level. Therefore, there is a need for budget rearrangement to be more effective and efficient. Fourth, Indonesia must gradually increase scholarship program for local students and foreign students, and increase the number of post graduates. With the increase in number of workers with higher education qualification through education reform, Indonesia will become a player with strong potential in regional and global labor sector.

As has been discuss before, in order to implement AEC in 2015, government of Indonesia must prioritize budget on improvement of workers education qualification. This includes making sure that the proportion of workers present in Indonesia at least has high school education. On the other hand, in the matter of education budget, the Government constitutionally allocates 20 percent of State Budget for education annually; however, the majority of it is still concentrated to pay teachers' wages. The increase of scholarship conferring also needs to be conducted in education sector by improving scholarship opportunities for local and foreign students. Through this scholarship program, Indonesia citizen can get more skills and there will be improvement of the number of Indonesia citizen graduated from university. Improvement of Indonesia workers with higher 
education qualification can make Indonesia a strong nation in regional and global labor market [21].

Education institutions are also demanded to be able to empower all existing resources in supporting implementation of education. Good implementation of education certainly requires an effective and efficient management system to be able to produce productivity commensurate with the demand and expectation of public. One of the challenges faced by Indonesia is in professional human resources (HR) availability. Putting all of these aside, improvement of professional human resources quality and good infrastructure are absolute requirements in increasing competitiveness of Indonesian labor in ASEAN. Improvement in information technology and availability of information technology infrastructure are vital in improving competency of Indonesian labor. Therefore, a national information technology framework is required to make Indonesian people ready to face global market [10].

Problems that Indonesia faces in education sector depict that in facing liberalization of labor in ASEAN, Indonesia must execute various arrangements of education implementation at national level. This arrangement will certainly contribute to improvement of HR quality to be able to compete with HR from other ASEAN countries in regional scale labor market. The formation of ASEAN Community in 2015 not only gives a number of challenges, but also opportunities for Indonesia. The benefitting factor of Indonesian demography will provide opportunity to utilize labor market in ASEAN. Only, this opportunity is not easy to take considering the vast percentage of Indonesian labors with low skills. Therefore, Indonesia can also utilize the opportunity of cooperation with other ASEAN countries in the matter of education cooperation to improve the skill of Indonesian HR.

In order to improve the quality of education, the Government has signed The Indonesian Qualification Framework (IQF) in 2011. IQF becomes primary standard in classification of academic education, vocational education, and professional education graduate competencies. Through IQF, the quality of learning process output can be standardized in the entire country. IQF also allows the qualification acknowledged by other countries, and supports cross countries education mobility. The government also provides various scholarship programs for lecturers from higher education institutions to study and/or to conduct research abroad since 2009. At the end of 2011, the government also declared a grant scheme of International cooperation assisting higher education institutions to develop policy, rule, guidance and procedure for conducting cooperation [25].

Meanwhile, in relation to higher education access, at the end of 2012, the Government with the Parliament had released Law Number 12 Year 2012 on Higher Education (UU DIKTI). One of the matters stipulated by UU DIKTI is about education access. Through this stipulation, access to higher education is extended by enlarging quota of students in universities. This is executed with various efforts such as facility and infrastructure assistance that supports learning process, establishment of various new universities, and opening of community polytechnic and academy. Other policy related to opening of higher education access is by conferring State University Operational Aid (BOPTN). BOPTN is meant to assist public in financing higher education. The total fund of BOPTN for 2012 and 2013 are IDR 2.7 trillion. Apart from BOPTN, the government through the Ministry of Education and Culture has also provided BIDIKMISI program, an educational program providing assistance for students from low economy family group (dikti.go.id, 2013).

\section{Conclusion}

In education sector, many countries face challenges in higher education sector. This is related to increase of demand for higher education access, and the need for improvement 
of higher education quality. Improvement of higher education quality is required for acquiring acknowledgement at regional and international levels. Considering regional commitment to build ASEAN Community in 2015, ASEAN countries are faced with a number of challenges in higher education, both in relation to education reform, public funding provision, education infrastructure provision, and improvement of teacher qualification. Moreover, higher education in ASEAN is also expected to be able to collaborate at regional scale to construct a strong foundation in ASEAN Community.

Although ASEAN Community is based on three pillars, education seems to be a vital element supporting formation of ASEAN Community. According to ASEAN Charter, collaboration in education and development of human resources will empower ASEAN people and reinforce ASEAN Community. Implementation of education in ASEAN countries is demanded to be able to develop various student capacities in terms of innovation and entrepreneurship. Moreover, for the realization of ASEAN Community 2015, educational institution must be able to stimulate the use of English and information technology. This can be conducted by stimulating science and technology in social economic activities of the public by educational institutions.

Indonesia also faces a number of challenges in education sector. Challenges in this sector are heavily related to the developing situation where Indonesian labors are dominated by workers with low skills. With the free mobility of labors in ASEAN, this can be the greatest challenge for Indonesia. Improvement of labor competitiveness in labor market at regional level must be conducted immediately. Education sector as the basis for development of human resources becomes the sector in real need of reform in facing ASEAN Community 2015.

Indonesian government needs to be serious in replying to the challenges of ASEAN Community 2015. Extension of education access, financing in education sector and improvement of educational infrastructure become the government's focus in improving Indonesian competitiveness in ASEAN.

\section{Acknowledgement}

This research is supported by Universitas Prof Dr Moestopo (Beragama), Jakarta, Indonesia.

\section{References}

[1] X. Shi, "The future of ASEAN energy mix: A SWOT analysis", Renewable and Sustainable Energy Reviews, vol. 53, (2016), pp. 672-680.

[2] A. A. Yajid and A. K. Rahmat, "The Challenge of Ratification and Application of Specific Regional Based Declaration for Railway Industry in ASEAN Mainland: The National Culture Perspective", Procedia-Social and Behavioral Sciences, (2015).

[3] S. Opasanon and S. Kitthamkesorn, "Border crossing design in light of the ASEAN Economic Community: Simulation based approach", Transport Policy, vol. 48, (2016), pp. 1-12.

[4] P. Srisuruk and L. Silanoi, "The Effect of Training Package Development in Preparing the Readiness for Secondary School Students in the Northeastern of Thailand toward Asean Community", Procedia-Social and Behavioral Sciences, (2015).

[5] C. Sukmadilaga, A. Pratama and S. Mulyani, "Good Governance Implementation in Public Sector: Exploratory Analysis of Government Financial Statements Disclosures across ASEAN Countries", Procedia-Social and Behavioral Sciences, (2015).

[6] C. Jitpaisanwattana, W. Pathumcharoenwattana and V. Tantawutho, "The Analysis and Synthesis on Education Management for Readiness Preparation of Thai Workforce in Accounting for the ASEAN Community", Procedia-Social and Behavioral Sciences, (2015).

[7] J. Zhang, J. Wang, S. D. Min, K. K. Chen and H. Huang, "Influence of curriculum quality and educational service quality on student experiences: A case study in sport management programs", Journal of Hospitality, Leisure, Sport \& Tourism Education, vol. 18, (2016), pp. 81-91.

[8] M. Niculescu, "The Quality of the Educational Process via Classroom Leadership", Procedia-Social and Behavioral Sciences, (2015). 
[9] M. Chalaris, S. Gritzalis, M. Maragoudakis, C. Sgouropoulou and A. Tsolakidis, "Improving quality of educational processes providing new knowledge using data mining techniques", Procedia-Social and Behavioral Sciences, (2014).

[10] "Facing ASEAN Economic Community 2015 (Menghadapi ASEAN Economic Community 2015)", accessed from http://www.radarcirebon.com/menghadapi-asean-economic-community-2015.html on 11 February 2015 at 14.00 .

[11] "Thailand to Focus More on Culture and Education toward Realizing the ASEAN Community", accessed from http://thailand.prd.go.th/view_news.php?id=5547\&a=3 on 10 February 2015 at 15.00 .

[12] ASEAN Secretariat, "ASEAN Integration by 2015 and Its Implications to Education in the Region", accessed http://seamolec.org/cnx/03/A_ASEAN/28Jan13_ASEC_ASEAN\%20Integration\%20and\%20implication $\% 20$ to\%20Southeast\%20Asia.pdf on 10 February 2015 at 13.00.

[13] M. N. Yaakub, "Challenges in Education towards the Realization of Asean Community 2015", accessed from http://www.site.rmutt.ac.th/cpscworkshop/materials/sp.pdf on 10 February 2015 at 09.00 .

[14] ASEAN Secretariat, "ASEAN 5-Year Work Plan on Education (2011-2015)", (2012).

[15] International Labour Organization and Asian Development Bank, "ASEAN Community 2015: Managing Integration for Better Jobs and Shared Prosperity", Bangkok, (2014).

[16] N. H. Nguyen, "Thai Workforce- Ready for Asean Economic Community 2015?", accessed from http://utcc2.utcc.ac.th/utccijbe/_uploads/InProcess/201409/THAI\%20WORKFORCE\%20READY\%20FOR\%20ASEAN\%20ECONOMIC\%20COMMUNITY\%202015.pdf on 11 February 2015 at 11.00

[17] P. Lavankura, "Internationalizing higher education in Thailand: Government and university responses", Journal of studies in international education, vol. 17, no. 5, (2013), pp. 663-676.

[18] T. S. Gilbert, "Enhancing Quality Education Thru the K+12 Program towards the Realization of Asean Community 2015 The Philippines Country Report", accessed from http://www.ppsta.net/forms/2014/others/PHILIPPINES\%20COUNTRY\%20REPORT.pdf $\quad$ on 10 February 2015 at 15.20 .

[19] H. Vutha, Cambodia's Preparedness for ASEAN Economic Community 2015 and Beyond, Development Research Forum Synthesis Report No. 07, (2014).

[20] "Answering Challenges of Higher Education in Indonesia (Menjawab Tantangan Pendidikan Tinggi di Indonesia)", accessed from http://dikti.go.id/blog/2013/01/24/menjawab-tantangan-pendidikan-tinggi-diindonesia/ on 13 February 2015 at 09.00.

[21] "Education Hampering Indonesia's Preparations for AEC in 2015", accessed from http://thejakartaglobe.beritasatu.com/news/education-hampering-indonesias-preparations-aec-2015/ on 11 February 2015 at 13.00 .

[22] Budiharjo, Integrated Quality Management-based on Science Education in Indonesia, International Journal on Advanced Science, Engineering, and Information Technology, vol. 6, no. 5, (2016), pp. 746756.

[23] T. Shawyun, Landscape of HEI and Quality Challenges in AEC 2015, International Journal of Business and Management, vol. II , no. 2, (2014)

[24] N. A. Wibisono, Indonesia Education: Is Indonesia's Workforce Ready for AEC 2015?, accessed from http://www.establishmentpost.com/aec-2015-indonesian-education-reform/ on 10 February 2015 at 12.30 .

[25] P. Umboh, Education for the ASEAN Community - The Case of Indonesia, Journal of ASEAN Studies, vol. 1 , no. 1, (2013), pp. 83-89 
International Journal of $u-$ and e- Service, Science and Technology Vol.10, No.4 (2017) 